\title{
EFFECTS OF PAR ON PLANT SPACING IN RELATION TO YIELD EFFICIENCY IN PEACH
}

\author{
Yamini Sharma ${ }^{1 *}$ and Harminder Singh \\ Punjab Agricultural University, Ludhiana, Punjab-141004, India \\ Keywords: Peach, PAR, Spacing, Yield
}

\begin{abstract}
Effects of PAR in relation with plant spacing in peach cultivar 'Shan-i-Punjab' during the year 2013-14 and 2014-15 were evaluated. The trees were trained to 4 different training systems and each system consisted of 2 spacings viz., $5 \times 3 \mathrm{~m}$ and $5 \times 2 \mathrm{~m}$. Daily PAR was recorded at morning, midday and evening and it was found that irrespective of planting distance maximum light interception was recorded at midday hours. Plants spaced at $5 \times 3 \mathrm{~m}$ received more light inside the canopy during full day which directly influenced number of fruits per tree, number of picking, fruiting density, yield efficiency, relative pattern of fruit maturity whereas, fruit yield per hectare was maximum in $5 \times 2 \mathrm{~m}$.
\end{abstract}

Narrow canopies are future of stone fruit production as selecting an appropriate orchard configuration will ensure easy equipment passage and reduce shading over the life of the orchard. The development of productive high-density peach orchards is often limited by the excessive vegetative growth of the trees that reduces productivity and quality. Improvement in light distribution and interception through canopy architecture have great impact on trees. If light becomes limiting, the fruiting zone will move higher above the ground with little fruiting in the lower portion of the tree. Optimized PAR absorption is necessary not only for avoiding barewood formation, but to have balanced and enough number of buds and also appropriate fruit coloring. Therefore, it is necessary to measure PAR levels, assess the effect of canopy architecture on light interception and its influence on fruitfulness.

The experimental work was done in the laboratory of Fruit Science department, Punjab Agricultural University, Ludhiana. Peach trees of cv. Shan-i-Punjab were planted at two spacings i.e. $5 \times 2 \mathrm{~m}$ and $5 \times 3 \mathrm{~m}$ and were trained to four training system viz., Y shaped, Hedge row, Espalier and V trellis. Trees were pruned every year in winter, and it consisted of a combination of heading back and selective thinning out of fruitful branches. PAR was taken at fortnightly intervals on clear days at three times (10 a.m., 1 and 4 p.m.) by recording the sensor output from a sun scan probe using a digital multi- voltmeter. Incoming solar radiation measurements (watt $/ \mathrm{m}^{2}$ ) were recorded one foot above the canopy and at the centre of upper and lower parts of the canopy by the quantam sensor facing upward. The quantam sensor was inverted one foot above the canopy to record the amount of reflected short wave radiation. This was calculated according to Singh and Dhaliwal (2007)

\{albedo (A)\}

Radiation intercepted in the upper part $=$ $\frac{\mathrm{I}\left(\mathrm{I}_{1}+\mathrm{A}\right)}{\mathrm{I}} \times 100=\mathrm{x} \%$

Radiation intercepted in the lower part $=$

$$
\frac{\mathrm{I}-\left(\mathrm{I}_{2}+\mathrm{A}\right)}{\mathrm{I}} \times 100-\mathrm{x} \%=\mathrm{y} \%
$$

*Author for correspondence: <yaminisharma811@gmail.com>. ${ }^{1}$ Krishi Vigyan Kendra, Gurdaspur 143521, India. 
Total interception by the tree canopy $=x \%+y \%$

Where,

$\mathrm{I}=$ Incoming solar radiation received above one feet of the tree canopy

$\mathrm{I}_{1}=$ Incoming solar radiation received in the upper part of the tree canopy

$\mathrm{I}_{2}=$ Incoming solar radiation received in the lower part of the tree canopy

A = Albedo (Reflected short wave radiation) (Singh and Dhaliwal 2007)

The observations on relative pattern of fruit maturity was calculated according to Singh (2001) by counting the number of mature fruits from the tagged branches, two days before the start of first picking in each year and calculated as:

$\frac{\text { Number of mature fruits }}{\text { Total number of fruits }} \times 100$

Fruiting density and yield efficiency was calculated by the formulae as suggested by Holtzhausen et al. (1988).

$$
\begin{aligned}
& \text { Fruiting density (Fruit number } / \mathrm{m} 3 \text { ) }=\frac{\text { Average fruit number per tree }}{\text { Average canopy volume per tree }} \\
& \text { Yield efficiency }(\mathrm{kg} / \mathrm{m} 3)=\frac{\text { Average frult load per tree }}{\text { Average canopy volume per tree }}
\end{aligned}
$$

The number of pickings, number of fruits per tree and fruit yield per hectare were recorded as per the standard procedure used in such studies. The data were subjected to ANOVA using statistical software SAS. The mean separation was done using least significant difference (Fisher's LSD) at $\leq 0.05$ following significant $F$ test.

The mean total radiation intercepted during the year was higher in $5 \times 3 \mathrm{~m}(56.73 \%)$ planted trees as compared to trees planted at $5 \mathrm{~m} \times 2 \mathrm{~m}(54.69 \%)$ in July irrespective of training systems and parts of canopy (Fig. 1). Muhammad and Singh (2007) reported that plant spacing had a great affect on the photo synthetically active radiation (PAR) so the ratios of blue, far-red, red far and blue red as a result of decreased plant density were increased. Similar results were recorded by Brar et al. (2013) who reported that at close spacing more vertical orientation of axillary shoots and leaves which leads to reduced interception as compared to wide spaced plants.

Plants experience a highly variable light environment over the course of the day. It was also recorded that radiation interception by the total part of the canopy (upper and lower) was higher between March to July during both the year 2013-14 and 2014-15 and after that a decrease was observed irrespective of training systems and spacings (Fig. 1). Mean radiation interception by the tree canopy was maximum (59.86\%) in the midday as compared to morning (54.06\%) and evening

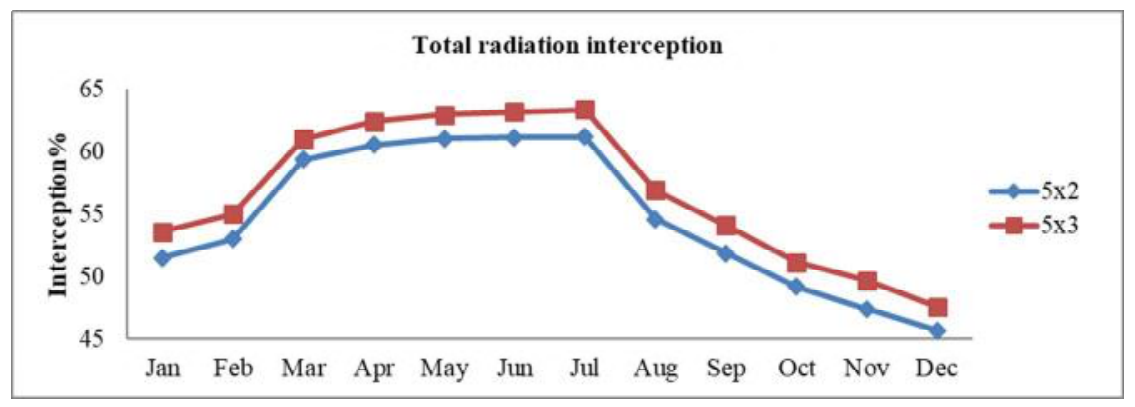

Fig. 1. Average daily radiation intercepted during the year by a peach tree at planting distance. 
(53.23\%) hours in all the training systems and spacings during the present studies (Fig. 2). It was recorded that PAR in the canopy during morning $(55.03 \%)$, midday $(60.83 \%)$ and evening hours $(54.36 \%)$ was higher in $5 \times 3 \mathrm{~m}$ planted trees as compared to morning $(53.10 \%)$, midday $(58.88 \%)$ and evening hours $(52.09 \%)$ of the trees planted at $5 \times 2 \mathrm{~m}$. Singh and Kanwar (2004) and Singh and Dhaliwal (2007) also observed highest radiation interception in the upper canopy part during midday (12.00 - $14.00 \mathrm{hrs)} \mathrm{in} \mathrm{peach} \mathrm{and} \mathrm{guava,} \mathrm{respectively.}$

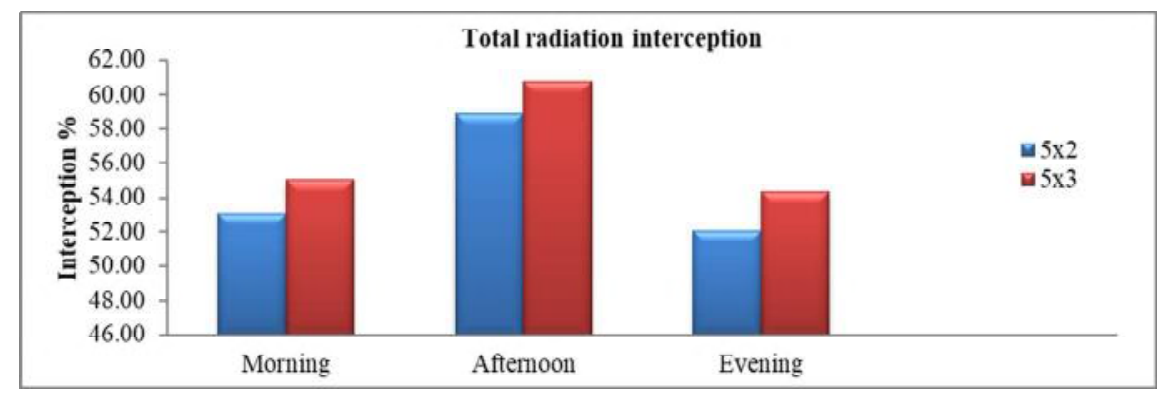

Fig. 2. Average interception of solar radiation by peach tree at different spacings at various time Interval.

Study revealed that trees planted at $5 \times 3 \mathrm{~m}$ attained early maturity $(52.17 \%)$ as compared to $5 \times 2 \mathrm{~m}$ planted trees $(50.30 \%$ ) (Table 1). This might be due to reduction in receiving radiant energy and reduction in substrate level production in $5 \times 2 \mathrm{~m}$ planted peach. According to Tabasi et al. (2013) sunlight is a crucial factor on fruit quality. They reported that increasing row spacing causes light to penetrate inside the canopy and earlier maturity. Similar finding was observed by Singh and Kanwar (2004) who reported that higher light penetration in the $6 \times 6 \mathrm{~m}$ planted trees had a positive effect on fruit maturity in peach. Similarly, Iyer and Rejo (2006) reported that closer plantings resulted in early productivity leading to early returns on capital.

Table 1. Effect of training systems and spacings on pattern of fruit maturity, number of fruit per tree.

\begin{tabular}{|c|c|c|c|c|c|c|c|}
\hline \multirow{2}{*}{$\begin{array}{l}\text { Training } \\
\text { systems }\end{array}$} & \multirow{2}{*}{$\begin{array}{l}\text { Spacings } \\
(\mathrm{m})\end{array}$} & \multicolumn{3}{|c|}{ Pattern of fruit maturity } & \multicolumn{3}{|c|}{ Number of fruit per tree } \\
\hline & & 2014 & 2015 & Mean & 2014 & 2015 & Mean \\
\hline \multirow[t]{3}{*}{ Y shaped } & $5 \times 2$ & 50.93 & 54.33 & 52.63 & 233.42 & 158.61 & 196.01 \\
\hline & $5 \times 3$ & 53.81 & 57.25 & 55.53 & 257.57 & 187.1 & 222.34 \\
\hline & Mean & $52.37^{\mathrm{c}}$ & $55.79^{c}$ & $54.08^{\mathrm{c}}$ & $245.50^{\mathrm{b}}$ & $172.85^{\mathrm{b}}$ & $209.17^{b}$ \\
\hline \multirow[t]{3}{*}{ Hedge row } & $5 \times 2$ & 33.09 & 36.55 & 34.82 & 215.88 & 141.41 & 178.65 \\
\hline & $5 \times 3$ & 34.41 & 38.05 & 36.23 & 231.63 & 160.75 & 196.19 \\
\hline & Mean & $33.75^{\mathrm{d}}$ & $37.30^{\mathrm{d}}$ & $35.53^{d}$ & $223.75^{\mathrm{c}}$ & $151.08^{\mathrm{c}}$ & $187.42^{\mathrm{bc}}$ \\
\hline \multirow[t]{3}{*}{ Espailer } & $5 \times 2$ & 54.97 & 60.99 & 57.98 & 205.87 & 138.25 & 172.06 \\
\hline & $5 \times 3$ & 56.97 & 62.21 & 59.59 & 222.94 & 157.83 & 190.38 \\
\hline & Mean & $55.97^{\mathrm{a}}$ & $61.60^{\mathrm{a}}$ & $58.78^{\mathrm{a}}$ & $214.40^{\mathrm{d}}$ & $148.04^{\mathrm{c}}$ & $181.22^{\mathrm{c}}$ \\
\hline \multirow[t]{3}{*}{$\mathrm{V}$ trellis } & $5 \times 2$ & 52.7 & 58.88 & 55.79 & 261.01 & 201.11 & 231.06 \\
\hline & $5 \times 3$ & 54.61 & 60.03 & 57.32 & 281.19 & 216.68 & 248.93 \\
\hline & Mean & $53.65^{b}$ & $59.46^{\mathrm{b}}$ & $56.55^{\mathrm{b}}$ & $271.10^{\mathrm{a}}$ & $208.89^{\mathrm{a}}$ & $239.99^{\mathrm{a}}$ \\
\hline \multirow{2}{*}{$\begin{array}{l}\text { Spacing } \\
\text { mean }\end{array}$} & $5 \times 2$ & $47.92^{\mathrm{b}}$ & $52.69^{b}$ & $50.30^{\mathrm{b}}$ & $229.04^{\mathrm{b}}$ & $159.85^{b}$ & $194.44^{\mathrm{b}}$ \\
\hline & $5 \times 3$ & $49.95^{\mathrm{a}}$ & $54.39^{\mathrm{a}}$ & $52.17^{\mathrm{a}}$ & $248.33^{\mathrm{a}}$ & $180.59^{\mathrm{a}}$ & $214.46^{\mathrm{a}}$ \\
\hline \multirow[t]{3}{*}{ LSD 0.05} & $\begin{array}{l}\text { Training } \\
\text { system }\end{array}$ & 0.46 & 0.5 & 0.38 & 5.23 & 4.71 & 24.28 \\
\hline & Spacing & 0.33 & 0.35 & 0.27 & 3.69 & 3.33 & 17.17 \\
\hline & $\begin{array}{l}\text { TS } \times \\
\text { Spacing }\end{array}$ & 0.66 & 0.71 & 0.54 & 7.39 & 6.66 & 34.34 \\
\hline
\end{tabular}


Spacing affected the number of fruits per tree significantly. Maximum fruit number (214.46) was recorded in $5 \times 3 \mathrm{~m}$ planted trees and it was significantly higher than the trees planted at $5 \times$ $2 \mathrm{~m}$ (194.44), irrespective of training systems (Table 1). According to Brar et al (2013) higher fruit number and yield per tree in plants at wider spacing might be due to their larger canopies. It might also be due to lower flower bud density recorded in closely planted trees during the course of this study. Similarly, Callesen and Wagenmakers (1989) reported that higher number of fruits per tree at wider spacing was due to higher tree volume and flowering which is in agreement with the present findings.

Data further showed that spacing also affected the productivity significantly. Highest yield $(15.90 \mathrm{t} / \mathrm{ha})$ was recorded in trees planted at $5 \times 2 \mathrm{~m}$ and it was significantly higher than the $5 \times$ $3 \mathrm{~m}$ planted trees $(12.24 \mathrm{t} / \mathrm{ha})$. These results show similarity with the results reported by Leon et al (2007) and Rana et al (1998). Higher yield per hectare at closer spacings was due to increased number of plants and foliage per hectare. This observation has a particular advantage under the experimental conditions in translating the available radiant energy into fruit yield and thereby increasing the income of already much stressed farmers, especially in the early years of peach tree.

Data presented in Table 2 reveal that fruiting density was significantly affected by spacings during the present investigation. Maximum fruiting density was obtained in $5 \times 2 \mathrm{~m}$ planted trees $\left(12.65\right.$ fruits $\left./ \mathrm{m}^{3}\right)$ which was significantly higher than trees planted at $5 \times 3 \mathrm{~m}\left(11.15 \mathrm{fruits} / \mathrm{m}^{3}\right)$ irrespective of training system. Robinson et al. (1991) found that differences in fruiting density were the results of either greater flower density or greater fruit set in apple. According to Hrotko et al. (2013) fruiting branches have linear correlation with tree density.

Table 2. Effect of training systems and spacings on fruiting density (fruit number $/ \mathrm{m}^{3}$ ) and yield efficiency in peach cv. Shan-i-Punjab.

\begin{tabular}{|c|c|c|c|c|c|c|c|}
\hline \multirow[b]{2}{*}{ Training systems } & \multirow[b]{2}{*}{ Spacings (m) } & \multicolumn{3}{|c|}{ fruiting density } & \multicolumn{3}{|c|}{ yield efficiency } \\
\hline & & 2014 & 2015 & Mean & 2014 & 2015 & Mean \\
\hline \multirow[t]{3}{*}{ Y shaped } & $5 \times 2$ & 17.35 & 5.9 & 11.62 & 1.28 & 0.45 & 0.93 \\
\hline & $5 \times 3$ & 14.53 & 6.08 & 10.26 & 1.14 & 0.49 & 0.83 \\
\hline & Mean & $15.94^{\mathrm{b}}$ & $5.95^{\mathrm{c}}$ & $10.94^{\mathrm{b}}$ & $1.21^{\mathrm{b}}$ & $0.47^{\mathrm{c}}$ & $0.88^{\mathrm{b}}$ \\
\hline \multirow[t]{3}{*}{ Hedge row } & $5 \times 2$ & 14.01 & 4.74 & 9.37 & 1.07 & 0.34 & 0.72 \\
\hline & $5 \times 3$ & 11.99 & 4.86 & 8.43 & 0.87 & 0.37 & 0.68 \\
\hline & Mean & $13.00^{\mathrm{b}}$ & $4.80^{\mathrm{d}}$ & $8.90^{c}$ & $0.97^{\mathrm{b}}$ & $0.35^{\mathrm{d}}$ & $0.70^{\mathrm{c}}$ \\
\hline \multirow[t]{3}{*}{ Espailer } & $5 \times 2$ & 25.22 & 8.95 & 17.08 & 2.25 & 0.79 & 2.72 \\
\hline & $5 \times 3$ & 20.34 & 8.11 & 14.22 & 1.84 & 0.72 & 2.17 \\
\hline & Mean & $22.78^{\mathrm{a}}$ & $8.53^{\mathrm{a}}$ & $15.65^{\mathrm{a}}$ & $2.04^{\mathrm{a}}$ & $0.75^{\mathrm{a}}$ & $2.44^{\mathrm{a}}$ \\
\hline \multirow[t]{3}{*}{$\mathrm{V}$ trellis } & $5 \times 2$ & 17.14 & 7.99 & 12.56 & 1.44 & 0.69 & 0.98 \\
\hline & $5 \times 3$ & 15.56 & 7.86 & 11.71 & 1.27 & 0.66 & 0.93 \\
\hline & Mean & $16.35^{\mathrm{b}}$ & $7.92^{\mathrm{b}}$ & $12.13^{\mathrm{b}}$ & $1.35^{\mathrm{b}}$ & $0.67^{\mathrm{b}}$ & $0.95^{\mathrm{b}}$ \\
\hline \multirow[t]{2}{*}{ Spacing mean } & $5 \times 2$ & $18.43^{\mathrm{a}}$ & $6.89^{\mathrm{a}}$ & $12.65^{\mathrm{a}}$ & $3.02^{\mathrm{a}}$ & $1.13^{\mathrm{a}}$ & $2.67^{\mathrm{a}}$ \\
\hline & $5 \times 3$ & $15.60^{\mathrm{b}}$ & $6.70^{\mathrm{a}}$ & $11.15^{\mathrm{b}}$ & $1.28^{\mathrm{b}}$ & $0.56^{\mathrm{b}}$ & $1.15^{\mathrm{b}}$ \\
\hline \multirow[t]{3}{*}{ LSD 0.05} & $\begin{array}{l}\text { Training } \\
\text { system }\end{array}$ & 3.93 & 0.62 & 2.04 & 0.32 & 0.05 & 0.15 \\
\hline & Spacing & 2.77 & 0.44 & 1.4 & 0.22 & 0.03 & 0.11 \\
\hline & $\mathrm{TS} \times$ Spacing & 5.55 & 0.88 & 11.42 & 0.45 & 0.07 & 0.22 \\
\hline
\end{tabular}




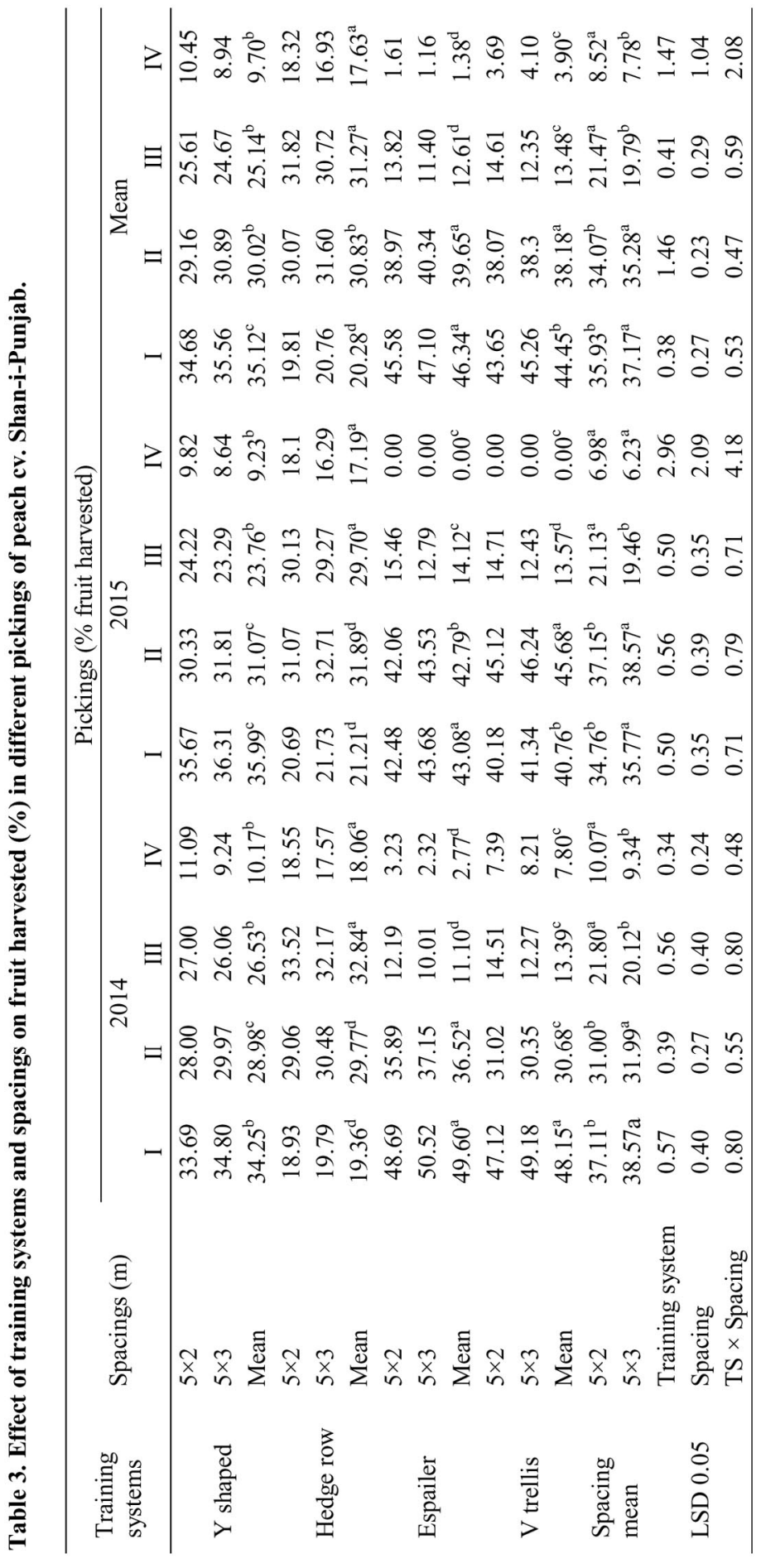


Maximum mean yield efficiency $\left(2.67 \mathrm{~kg} / \mathrm{m}^{3}\right)$ was recorded in trees planted at $5 \times 3 \mathrm{~m}$ and it was significantly higher than $5 \times 2 \mathrm{~m}$ planted trees $\left(1.15 \mathrm{~kg} / \mathrm{m}^{3}\right)$ irrespective of training systems (Table 2). Rieger et al. (1997) reported that yield efficiency increased with an increase in tree spacings in peach. Similar finding was recorded by Brar et al. (2013) in guava.

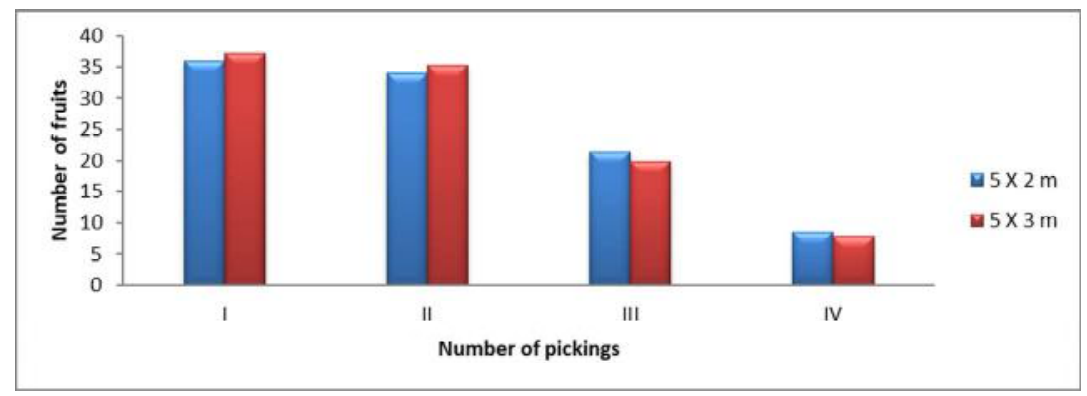

Fig. 3. Effect of spacings on fruit harvested (\%) in different pickings of peach cv. Shan-i-Punjab.

The spacings had a significant effect on the percentage of fruit harvested at different picking during the present studies. The fruits harvested from $5 \times 3 \mathrm{~m}$ planted trees were in first $(37.17 \%)$, second (35.28\%), third (19.79\%) and fourth (7.78\%) picking. This values reduced as compared to trees planted at $5 \times 2 \mathrm{~m}$ in which less fruit was picked from first (35.93\%) and second (34.07\%), third (21.47\%) and fourth (8.52\%) picking (Table 3). From the study it may be suggested that sufficient availability of sunlight for peach is one of the most important factors to get early, uniform and good quality fruits.

\section{References}

Brar JS, Dhaliwal HS, Bal JS and Singh SP 2013. Canopy Microclimate and Reproductive Behavior of 'L49' Guava Plants at Different Spacings, Indian J. Ecol. 40(1): 77-82.

Callesen O and Wagenmakers OS 1989. Effect of tree density, tree height and rectangularity on growth, flowering and fruit production. Acta Hort. 243: 141-148.

Holtzhausen LC, Grundlingh JA, Niven PNF and Maritz J 1988. Nine rootstocks evaluated for four Navel cultivars in the Eastern Cape. Proc 6th Int Citrus Congr, Tel Aviv, Israel pp 33-45.

Hrotkó K 2013. Development in fruit trees production systems. Agro. Life Scient J. 2(1): 28-35.

Iyer, CPA and Reju MK 2006. High Density Planting in Tropical Fruits: Principles and Practices. Lucknow, International Book Distributing, xi, p. 260

León L, Rosan RDL, Rallo L, Guerrero N and Barranco D 2007. Influence of spacing on the initial production of hedgerow 'Arbequina' olive orchards. Span. J. of Agric. Res. 5(4): 554-558.

Muhammad A and Singh A 2007. Intra-row spacing and pruning effects on fresh tomato yield in Sudan Savanna of Nigeria. J. Plant. Sci. 2:153-161.

Rana HS, Awasthi RP, Sharma RM and Jha A 1998 Effect of training system on canopy physiology, fruit yield and quality of peach. J. Hill. Rec. 11(1): 38-42.

Rieger M, Myers S C, Baritt B H and Kappel F 1997. Growth and yield of high-density peach trees as influence by spacing and rooting volume. Acta Hort. 43(1): 611-616.

Robinson TL, Lakso AN and Carpenter SG 1991. Canopy development, yield, and fruit quality of 'Empire' and 'Delicious' apple trees grown in four orchard production systems for ten years. J. Am. Soc. Hortic. Sci. 116: 179-187. 
Sarrwy S, Mostafa EAM and Hassan HFA 2012. Growth, Yield and Fruit Quality of Williams Banana as Affected by Different Planting Distances. Intern. J. of Agric. Res. 7(5): 266-275.

Singh H 2001. Effect of planting densities and training systems on light interception, growth, productivity and nutrient composition of peach. Ph.D. Dissertation, Punjab Agricultural University, Ludhiana, India.

Singh H and Kanwar JS 2004. Effect of planting distances and training systems on light interception in high density plantations of peach trees grown under subtropical conditions. Acta Hortic. 662: 225-229.

Singh A and Dhaliwal GS 2007. Solar radiation interception and its effect on physical characteristics of fruits of guava cv. Sardar. Acta Hort. 735: 297-02.

Tabasi A, Nemati A, Nemati H and Akbari M 2013. The Effects of Planting Distances and Different Stages of Maturity on the Quality of Three Cultivars of Tomatoes (Lycopersicon esculentum Mill). Not. Sci. Biol. 5(3): 371-375.

(Manuscript received on 8 June, 2019; revised on 11 December, 2020) 